\title{
In situ aerosol optics in Reno, NV, USA during and after the summer 2008 California wildfires and the influence of absorbing and non-absorbing organic coatings on spectral light absorption
}

\author{
M. Gyawali ${ }^{1}$, W. P. Arnott ${ }^{1}$, K. Lewis ${ }^{1}$, and H. Moosmüller ${ }^{2}$ \\ ${ }^{1}$ Physics Department, University of Nevada, Reno, Nevada System of Higher Education, 1664, N. Virginia Street, \\ Reno, NV, 89557, USA \\ ${ }^{2}$ Desert Research Institute, Nevada System of Higher Education, 2215 Raggio Parkway, Reno, NV, 89512, USA
}

Received: 2 May 2009 - Published in Atmos. Chem. Phys. Discuss.: 26 June 2009

Revised: 25 September 2009 - Accepted: 25 September 2009 - Published: 23 October 2009

\begin{abstract}
Hundreds of wildfires in Northern California were sparked by lightning during the summer of 2008 , resulting in downwind smoke for the months of June and July. Comparisons are reported for aerosol optics measurements in Reno, Nevada made during the very smoky month of July and the relatively clean month of August. Photoacoustic instruments equipped with integrating nephelometers were used to measure aerosol light scattering and absorption coefficients at wavelengths of $405 \mathrm{~nm}$ and $870 \mathrm{~nm}$, revealing a strong variation of aerosol light absorption with wavelength. Insight on fuels burned is gleaned from comparison of Ångström exponents of absorption (AEA) versus single scattering albedo (SSA) of the ambient measurements with laboratory biomass smoke measurements for many fuels. Measurements during the month of August, which were largely unaffected by fire smoke, exhibit surprisingly low AEA for aerosol light absorption when the SSA is highest, again likely as a consequence of the underappreciated wavelength dependence of aerosol light absorption by particles coated with nonabsorbing organic and inorganic matter. Coated sphere calculations were used to show that AEA as large as 1.6 are possible for wood smoke even with non-absorbing organic coatings on black carbon cores, suggesting care be exercised when diagnosing AEA.
\end{abstract}

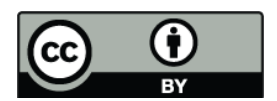

Correspondence to: M. Gyawali (gyawalim@unr.nevada.edu)

\section{Introduction}

Biomass burning is a significant global source of trace gases and particles in the atmosphere. Optical properties of aerosols emitted from biomass burning are highly uncertain due to the uncertainty in combustion factors, burned areas, and the types of fuels the flaming and smoldering phase of burning (Ito and Penner, 2004), as well as rapidly changing atmospheric conditions (Chen et al., 2007; Hudson et al., 2004). Biomass burning aerosols grow upon aging due to coagulation and condensation and exhibit increased scattering coefficients (Johnson et al., 2008). Biomass burning aerosols significantly alter the Earth's radiation by scattering and absorbing solar radiation (Chen et al., 2006; Lewis et al., 2008). Biomass burning has short- and long-term consequences on the radiation budget (Naik et al., 2007), as increased light scattering by particles cools the Earth's surface but increased $\mathrm{CO}_{2}$ warms the surface in the long-term. Accelerating death rates of old forest trees may soon strongly impact short- and long-term atmospheric composition.

Wildfire activity in the western US has increased in recent decades mainly due to severe droughts and abundant fuels (Westerling et al., 2006). California is among the states that have the highest wildfire activity, generally starting midMay and ending in October (Pfister et al., 2008). In summer 2008, Northern California lightning triggered most of 2780 individual fires observed, burning $4686 \mathrm{~km}^{2}$ (http://en. wikipedia.org/wiki/Summer_2008_California_wildfires). At times, smoke from California wildfires can be observed moving from the west to east coast (Fig. 1, upper panel; Hoff et al., 2005). 


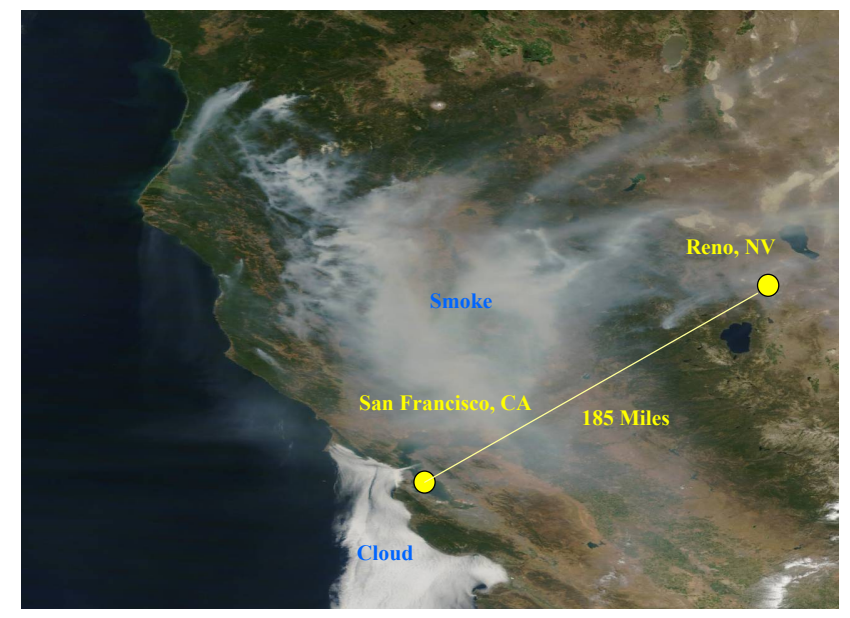

Urban Aerosol

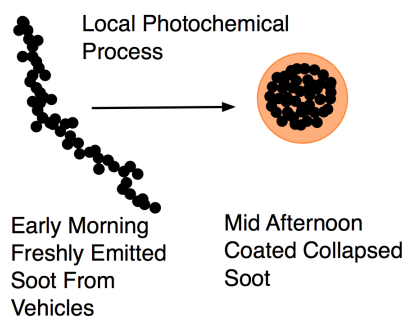

Fig. 1. Upper panel: Satellite image of smoke extending from northern California to Reno, Nevada on 10 July 2008. The smoke sources and wind trajectory were similar for much of July. Beneath panel: Conceptual model of emission and aging of urban and biomass burning aerosol.

In this study, in situ optical characteristics of summer 2008 California wildfire aerosols are reported and compared with those from urban pollution. A dual-wavelength photoacoustic instrument operating simultaneously at $405 \mathrm{~nm}$ and $870 \mathrm{~nm}$ was used for measurement of aerosol light absorption and scattering (Lewis et al., 2008). Simultaneous measurement at these two wavelengths provides insight into the optical characteristics of black carbon (BC) or "soot" potentially modified by non-absorbing organic carbon (OC) coatings and light absorbing organic carbon (LAOC) or "brown carbon" $(\mathrm{BrC})$, the two main light-absorbing carbonaceous substances in the atmosphere (Moosmüller et al., 2009). The photoacoustic instrument draws sample air continuously through its acoustical resonator and illuminates it with power-modulated laser radiation at the acoustic resonance frequency of the resonator. Heating of the particles takes place due to the absorption of laser radiation, and the heat rapidly transfers to the surrounding air. The resulting periodic pressure fluctuations are measured by a microphone (Arnott et al., 1999). Scattering measurements are carried out in the photoacoustic instrument with the technique of reciprocal nephelometry (Lewis et al., 2008; Mulholland and Bryner, 1994; Rahmah et al., 2006). The instrument is calibrated by using a high concentration of absorbing gas or kerosene-flame soot or laboratory-generated aerosol with extinction dominated by scattering (Arnott et al., 2000; Lewis et al., 2008). Generally, absorption by BC in the region from $370 \mathrm{~nm}$ to $950 \mathrm{~nm}$ is inversely proportional to the wavelength, whereas absorption due to $\mathrm{BrC}$ is stronger toward $\mathrm{UV}$ regions (Moosmüller et al., 2009). Hence multi-wavelength measurements are needed to adequately address absorption characteristics of carbonaceous aerosols in the atmosphere (Andreae and Gelencsér, 2006). Photoacoustic absorption measurements are not affected by filter matrix artifacts that can be complicated by organic coatings (Lack et al., 2008; Subramanian et al., 2007).

In addition to truly light-absorbing organic carbon (LAOC), light absorption of BC can be enhanced by nonabsorbing OC that we will refer to as "apparently light absorbing carbon" (ALAOC), independent of whether the coating absorbs light or not. Our focus is the total affect of the coating on the fractal soot core, part of which may be to collapse the core, thereby changing its absorption. It is easy to confuse LAOC and ALAOC. In LAOC, black carbon cores are coated with organic matter that typically absorbs more strongly at shorter wavelengths than at longer wavelengths. However, for ALAOC, we acknowledge in this definition that there may be strong wavelength dependence in the lightabsorption amplification of a black carbon core by organic coatings that do not absorb light at all. Later work will refine the definition of the Ångström exponent of absorption to clearly distinguish between ALAOC and LAOC, and it will be shown that filter-based methods do not diagnose ALAOC well because particle-bound OC can surround the filter media. Here, we performed an investigation to elucidate the likely error involved in naively interpreting the Ångström exponent of absorption measurements solely in terms of LAOC without considering ALAOC.

\section{Measurements and analysis}

Figure 1, upper panel, shows a satellite image of smoke extending from the Northern California east, beyond Reno, Nevada on 10 July, which was the smokiest day of summer 2008 in Reno. The image shows that Reno is about 100 miles from the center of the major wildfire sources of July 2008. This smoke source and wind trajectory were similar for much of July. The dual-wavelength photoacoustic instrument was operated continuously from the starting of July to the end of August 2008, where measurements were carried out for 22 days in July and 27 days in August (interrupted for instrument calibration). The measurements were obtained at the Physics building of the University of Nevada, Reno, USA. Besides having a couple of minor roads circling the University, two freeways are nearly one mile away from the campus which is in the center of the city. 
Detailed examinations of $\mathrm{BC}$ particles show that they consist of agglomerations of small spherical spherules (Liu et al., 2008). The spherules bind together due to the electrostatic force (Bruce et al., 1991). During the aging process, coating $\mathrm{BC}$ particles with water soluble compounds like ammonium sulfate makes them hydrophilic due to condensation, coagulation, and photochemical oxidation (Oshima et al., 2009).

Figure 1, beneath panel, shows the conceptual model of aging of urban aerosol and biomass burning aerosol (especially for primary emission of ponderosa pine-like burning aerosol) in which small BC cores are heavily coated with organics (Lewis et al., 2009). Open-chain BC particles from biomass burning become closely packed spheres due to water uptake and condensation of inorganic and organic compounds (Hallett et al., 1989). Immediately after emission from the source the $\mathrm{BC}$ particles might have internal and external mixing states. With the aging process in the atmosphere, however, the simple shell-core model (described later) is plausible for biomass burning aerosols (Martins et al., 1998) and mid-day urban aerosol coated with generated particulate matter.

\subsection{Aerosol extinction variation}

The extinction (sum of absorption and scattering) variation presented here was the daily average of half-hour measurements for the period of July and August 2009 respectively. The photoacoustic measurements of absorption and scattering coefficients have $5 \%$ and $15 \%$ relative uncertainty respectively (Lewis et al., 2008). The time series of scattering and absorption (half-hour average) measurements reached maximum values of $1230 \mathrm{Mm}^{-1}$ and $106 \mathrm{Mm}^{-1}$ at $405 \mathrm{~nm}$ and $476 \mathrm{Mm}^{-1}$ and $30 \mathrm{Mm}^{-1}$ at $870 \mathrm{~nm}$ on 10 July 2008 and of $154 \mathrm{Mm}^{-1}$ and $18 \mathrm{Mm}^{-1}$ at $405 \mathrm{~nm}$ and $52 \mathrm{Mm}^{-1}$ and $7 \mathrm{Mm}^{-1}$ at $870 \mathrm{~nm}$ on 30 July 2008 respectively. Daily maximum scattering and absorption were decreasing between these days. Between 5 July to 10 July, scattering and absorption coefficients were higher for both wavelengths but less than the maximum values mentioned above. Similarly, the time series of scattering and absorption coefficients maximized at $129 \mathrm{Mm}^{-1}$ and $28 \mathrm{Mm}^{-1}$ at $405 \mathrm{~nm}$ and $64 \mathrm{Mm}^{-1}$ and $11 \mathrm{Mm}^{-1}$ at $870 \mathrm{~nm}$ on 5 August 2008. These higher values in early August might be due to some sporadic smoke in the local area, but of much lower magnitude than in July. Slightly lower values of scattering and absorption were found from 11 to 15 August. For the rest of the month these values were significantly less. In Mexico City, due to the diurnal change in the primary aerosol sources and photochemically-generated secondary aerosol, the scattering was maximum several hours later in the day than absorption (Paredes-Miranda et al., 2009). In our study, scattering contributed most of the extinction at both $405 \mathrm{~nm}$ and $870 \mathrm{~nm}$ for both months. Evidence of vehicular emission dominance for the extinction in August was apparent in the aerosol extinction variation (Fig. 2) with the maximum in extinction

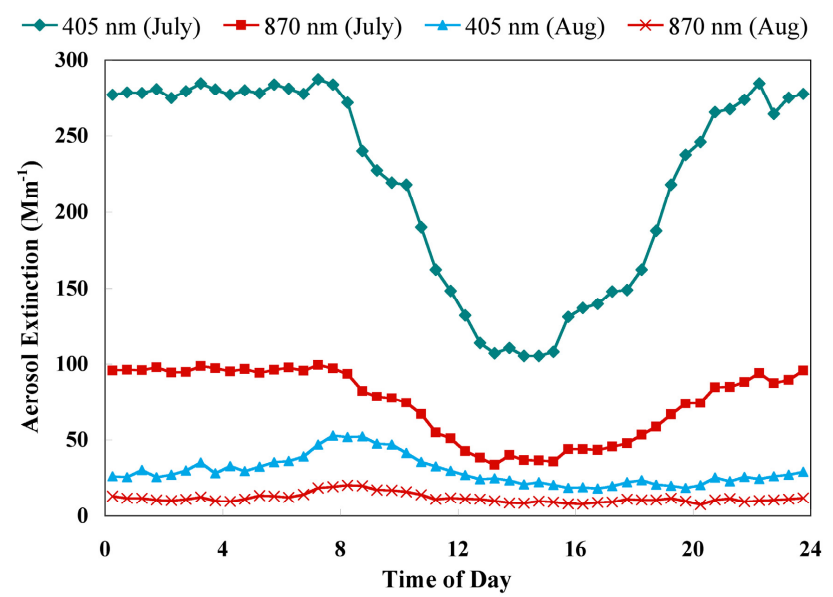

Fig. 2. Monthly averaged, diurnal aerosol extinction at $405 \mathrm{~nm}$ and $870 \mathrm{~nm}$ for July and August 2008. The photoacoustic absorption coefficient and scattering coefficient measurements have relative uncertainties of $5 \%$ and $15 \%$ respectively.

around the morning rush hour (from 6 a.m. to 11 a.m.) and nearly symmetrical low values on either side of the maximum for both $405 \mathrm{~nm}$ and $870 \mathrm{~nm}$ in August. In contrast, morning rush hour made only a small contribution to extinction in July. Extinction starts to decrease from 8 a.m. to a minimum around 1 p.m. and starts to increase continuously. These variations of extinction at both $405 \mathrm{~nm}$ and $870 \mathrm{~nm}$ in July exhibited the delaying effect of smoke on daytime boundary layer development (Rissler et al., 2006).

The monthly averaged diurnal aerosol extinction as a function of time of day (Fig. 2) indicates strong impacts of biomass aerosol in July compared to August at both $405 \mathrm{~nm}$ and $870 \mathrm{~nm}$. The extinction for July shows a clear diurnal pattern, with aerosol extinction decreasing gradually after 8 a.m. due to expansion of the boundary layer and increased wind speed diluting the plume. For August, a morning rush hour peak was observed from 6 a.m. to 11 a.m. coinciding with increased traffic volume at a time when boundary layer dilution is near its minimum and wind speeds are still low.

\subsection{Naive estimate of LAOC: ALAOC}

The apparent light absorption coefficient $\beta_{\mathrm{ALAOC}}$ due to organic carbon aerosol at $405 \mathrm{~nm}$ is written as

$\beta_{\text {ALAOC }}=\beta_{\text {abs }}(405 \mathrm{~nm})-\beta_{\text {abs }}(870 \mathrm{~nm}) \times 870 / 405$

where $\beta_{\text {abs }}(405 \mathrm{~nm})$ and $\beta_{\text {abs }}(870 \mathrm{~nm})$ are the aerosol absorption coefficients at 405 and $870 \mathrm{~nm}$, respectively. Here, the assumption is that $\mathrm{BC}$ absorbs both at $405 \mathrm{~nm}$ and $870 \mathrm{~nm}$ whereas LAOC absorbs strongly at $405 \mathrm{~nm}$ and negligibly at $870 \mathrm{~nm}$. The second term is the equivalent BC absorption at $405 \mathrm{~nm}$ assuming inverse wavelength dependence. Equation (1) acknowledges that some of the relative enhancement of absorption at $405 \mathrm{~nm}$ may be due to wavelength selective 


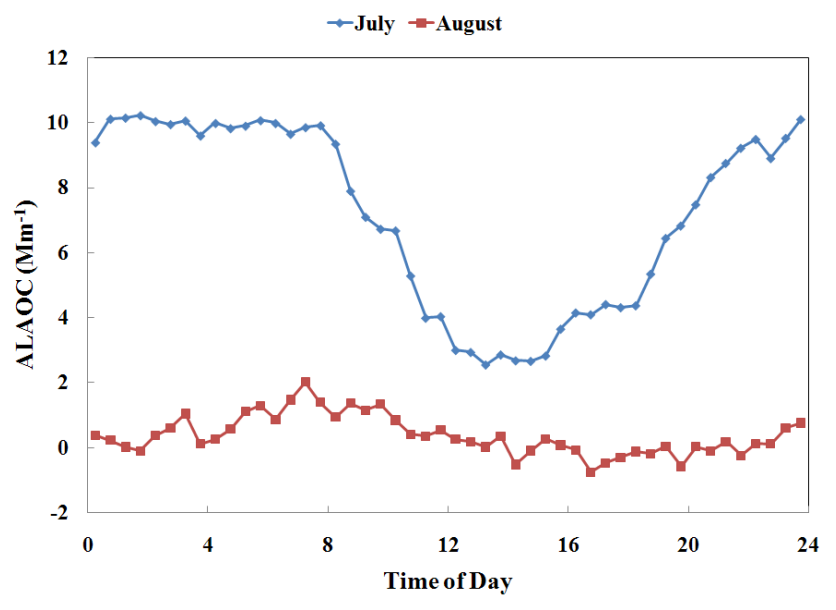

Fig. 3. Monthly averaged, diurnal apparently light-absorbing organic carbon (ALAOC) for July and August 2008.

amplification by a non-absorbing organic coating, in addition to any contribution by organic carbon that may absorb strongly at $405 \mathrm{~nm}$ and not at $870 \mathrm{~nm}$. Figure 3 shows the calculated monthly averaged ALAOC for the months of July and August. ALAOC was higher for July and almost nonexistent for August, which is consistent with the notion that organic matter emission from motor vehicles does not contain strong chromophores nor is abundant enough to cause strong coating effects. In addition, the BC core size for wood smoke is much smaller than for vehicular emissions. In July, the absorption due to ALAOC peaked at $10 \mathrm{Mm}^{-1}$, suggesting that biomass burning was the main source of ALAOC during our measurements.

\subsection{Single Scattering Albedo (SSA)}

Single scattering albedo (SSA) is defined as the ratio of scattering coefficient to extinction coefficient. Figure 4 illustrates monthly averaged SSA for $405 \mathrm{~nm}$ and $870 \mathrm{~nm}$. It depicts the contrasts between SSA for the months of July and August, during which aerosol absorption was dominated by wildfire aerosols and vehicular emissions, respectively, and highlights the different optical properties of the aerosols measured during this time period. It is noteworthy that calculated SSA was consistently higher at $870 \mathrm{~nm}$ than at $405 \mathrm{~nm}$ during July where SSA at $870 \mathrm{~nm}$ varies from 0.88 to 0.96 and SSA at $405 \mathrm{~nm}$ varies from 0.88 to 0.93 . This can be attributed to the large proportion of ALAOC in wildfire aerosol transport from California that preferentially absorbs radiation in the UV region (Andreae and Gelencsér, 2006) thereby lowering SSA at $405 \mathrm{~nm}$. Contrary to this observation, during August SSA at $405 \mathrm{~nm}(0.71-0.97)$ was in general higher than SSA at $870 \mathrm{~nm}(0.68-0.95)$ suggesting the dominance of the $\mathrm{BC}$ emission from vehicles with absorption coefficients inversely proportional to the wavelength. Also apparent from Fig. 4 is the strong diurnal cycle on SSA, with minima in the

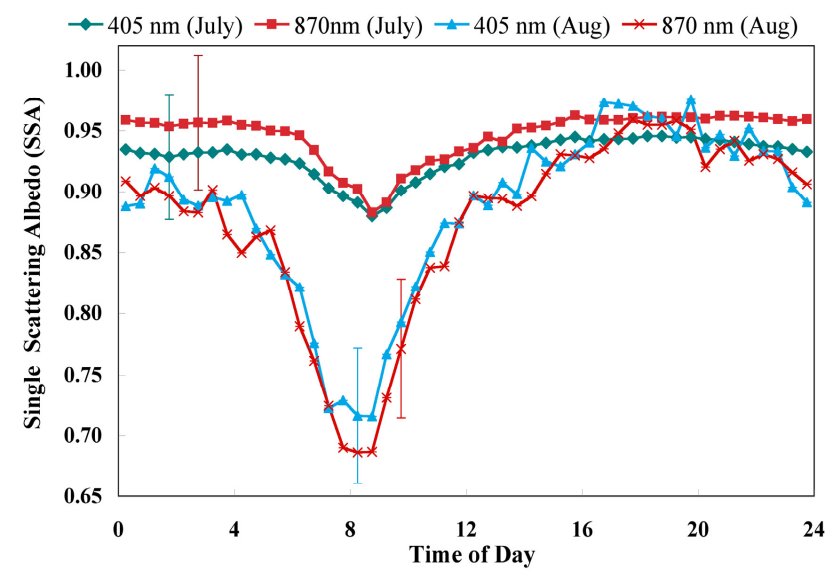

Fig. 4. Monthly averaged, diurnal aerosol SSA for $405 \mathrm{~nm}$ and $870 \mathrm{~nm}$ for the months of July and August 2008. SSA is higher for the smoky month of July. Note the minimum around the morning rush hour due to higher vehicular emissions. LAOC causes the SSA at $405 \mathrm{~nm}$ to be lower than at $870 \mathrm{~nm}$ in July. Uncertainty on SSA was determined by assuming 5\% relative uncertainty in photoacoustic absorption coefficient measurements and $15 \%$ relative uncertainty in scattering coefficient measurements.

morning rush hour (6-10 a.m.) and maxima on either side. This can be explained in terms of local conditions associated with rush hour vehicular emissions and mixing of the aerosol with development of the boundary layer. Photochemical activity during daytime and the growth of particle size might have increased scattering activity of the aerosol that causes the higher value of SSA at both wavelengths in the later part of day.

\section{4 Ångström Exponent of Absorption (AEA)}

The wavelength dependence of absorption is conventionally quantified using the AEA $\left(\alpha_{\mathrm{abs}}\right)$, which for the wavelengths of 405 and $870 \mathrm{~nm}$ can be written as

$\alpha_{\mathrm{abs}}=-\ln \left[\beta_{\mathrm{abs}}(405 \mathrm{~nm}) / \beta_{\mathrm{abs}}(870 \mathrm{~nm})\right] / \ln [405 / 870]$,

where $\beta_{\mathrm{abs}}$ (405) and $\beta_{\mathrm{abs}}$ (870) are the absorption coefficients at 405 and $870 \mathrm{~nm}$, respectively.

A plot of the monthly averaged, diurnal Ångström exponent of absorption (AEA) for $405-870 \mathrm{~nm}$ is shown in Fig. (5). Strong diurnal cycles of AEA during July and August are apparent in these observations. This clearly distinguishes the dependence of AEA for the months of July and August. During July, AEA varies from 1.42 to 2.07, and is consistent with the measurements reported elsewhere for biomass burning aerosols (Bergstrom et al., 2007; Clarke et al., 2007; Kirchstetter et al., 2004). The diurnal pattern of AEA for July shows it's minimum around morning rush hour which can be attributed to local dominance of vehicular emission of black carbon. During the "normal" month of August AEA varies from 0.88 to 1.28 . Most of the AEA values are 
closer to 1.0 during the morning rush hour and until afternoon as observed by the same authors and are described as the characteristics of black carbon or "soot" (Moosmüller et al., 2009). AEA starts to decrease in the afternoon and is at a minimum (0.88) in the later part of the day. At this time of day, the concentration of $\mathrm{BC}$ decreases with expansion of the boundary layer; but mixing, coating, and coagulation of $\mathrm{BC}$ with organic and inorganic aerosols affects its absorption in the diluted state. The enhancement might be slightly greater for $870 \mathrm{~nm}$ than for $405 \mathrm{~nm}$ at this time, consistent with low AEA values. Further, our simulations of AEA show the possibility of getting AEA values less than one for uncoated as well as coated carbon spheres.

Bergstrom et al. (2007) pointed out that the observation of AEA less than one is interesting and might be due to measurement uncertainties or to slightly larger values of the imaginary part of the refractive index at longer wavelengths for certain particles. Very low values of AEA have been reported without explanation for different situations (Bergstrom et al., 2007; Clarke et al., 2007; Roden et al., 2006; Subramanian et al., 2007; Yang et al., 2009). Clark et al. (AGU poster, 2005) has mentioned an AEA from 0.3 to 1.3 for urban air.

\subsection{Comparison with laboratory observations}

A comparison of optical properties of California wildfire smoke aerosol of summer 2008 was made with the optical properties of emissions from laboratory combustion of wildland and agricultural fuels in the Fire Science Laboratory of the USFS in Missoula, Montana (Lewis et al., 2008) as shown in Fig. 6. This comparison reveals that the optical properties of the California wildfire smoke aerosol of summer 2008 are closest to those of emissions from the combustion of different pine fuels. The observed SSA at Reno, Nevada of the California wildfire of summer 2008 was slightly greater than observed at the laboratory, possibly due to the increase of SSA during about six hours of aging since emission (Abel et al., 2003) and also possibly influenced by differences in fuel moisture and combustion conditions.

\subsection{Simulations and discussion}

The optical model of a highly absorbing BC core surrounded by a nonabsorbing shell is suggested for biomass burning aerosols (Martins et al., 1998) and for aged atmospheric soot (Bond and Bergstrom, 2006). However, this model may be unreliable for freshly emitted aerosols and long chain aggregates of BC particles near the source in urban locations. Shell-core model may overestimate aerosol light absorption by less than $15 \%$ in comparison to the random location of soot agglomerates (Fuller et al., 1999). This overestimate is due to the focusing of electromagnetic energy at the BC core due to lensing (Redemann et al., 2001). Laboratory investigations have been conducted to confirm the atmospheric BC

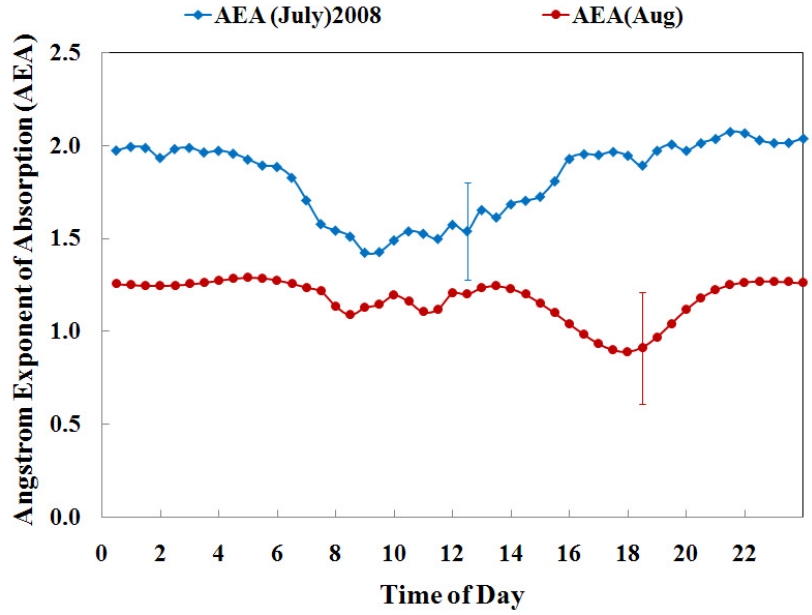

Fig. 5. Monthly averaged, diurnal aerosol AEA (405-870 nm) for the months of July and August vs. time of day. Uncertainty on AEA was determined by assuming 5\% relative uncertainty in photoacoustic absorption coefficient measurements.

aerosol coating effect on absorption (Schnaiter et al., 2005) in which soot particles were coated with secondary organic matter. Schwarz et al. (2008) discussed use of the shell-core approach for in situ measurements of light absorption in the tropical atmosphere. The coating on BC particles increases with altitude to the lower stratosphere (Schwarz et al., 2008).

Ponderosa pine and other pine species were typical fuels for the Northern California wildfires in 2008. In primary emissions of smoke from burning ponderosa pine, a mass fraction of less than $1 \%$ black carbon and around $99 \%$ organic matter was observed, and the black carbon core diameter was typically $50 \mathrm{~nm}$ (Lewis et al., 2009). The fractal structure of biomass burning aerosols becomes compacted during atmospheric aging (Chakrabarty et al., 2007) and increasingly spherical due to a coating of secondary species like organic matter, and nitrate or sulfate species from gas to particle conversion (Martins et al., 1998).

In August 2008, local-traffic-related emissions were the dominant black carbon source. Aerosol absorption measurements in the early morning are dominated by freshly emitted soot particles having low fractal dimension whereas within three hours after sunrise, absorption is due to photochemically-aged soot that is typically more hygroscopic than fresh soot (Moffet and Prather, 2009). The soot core size after coating is typically around $200 \mathrm{~nm}$ (Moffet and Prather, 2009).

The shell-core model for aerosol light absorption and scattering was used to explore the parameter space of AEA relevant to observations. The aim of the simulations presented here was to investigate theoretically possible variations on AEA for uncoated and coated carbonaceous spheres. The core refractive index was taken to be wavelength independent. For uncoated BC spheres with a complex refractive 


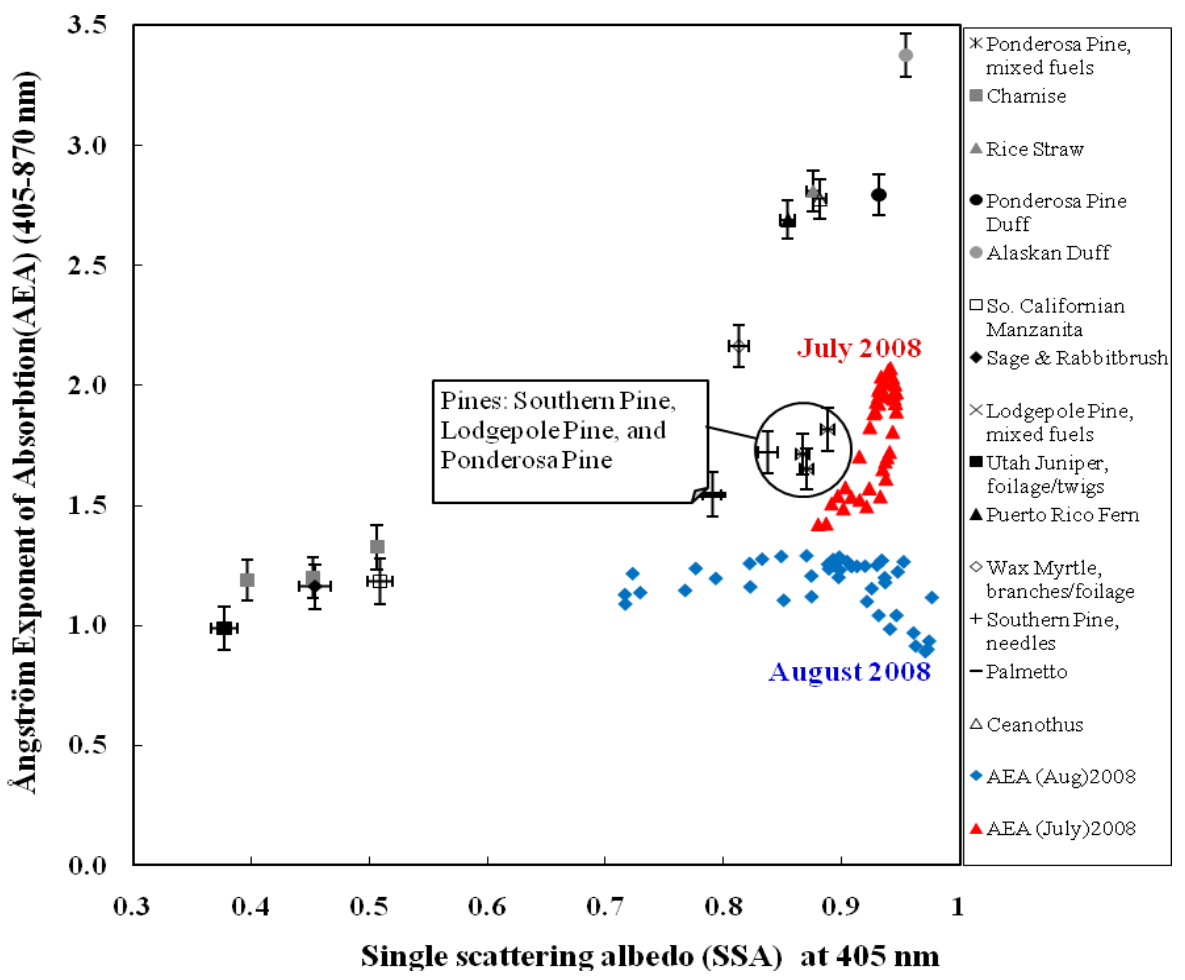

Fig. 6. A comparison of monthly averaged, diurnal Ångström exponent of absorption (AEA) versus single scattering albedo (SSA) at $405 \mathrm{~nm}$ for the months of July and August 2008 with the AEA and SSA of laboratory-burned fuels. The comparison illustrates that the optical properties of California wildfire aerosols of 2008 are similar to pine smoke aerosols.

index of $(1.55,0.8 \mathrm{i})$, AEA for 405 and $870 \mathrm{~nm}$ varies from 1.0 to 1.1 and to -0.24 , as function of the core diameter as shown in Fig. 7. AEA increases to about 1.11 for a core diameter of about $0.07 \mu \mathrm{m}$ and then decreases continuously, reaching a minimum of about -0.24 around $0.72 \mu \mathrm{m}$ and increases towards its geometrical limit of zero for large spheres.

The effects of non-absorbing (refractive index 1.5, 0.0 i), and absorbing coatings (refractive index 1.5, 0.012 $\mathrm{i}$ at $405 \mathrm{~nm}$ and 1.5, $0.0 \mathrm{i}$ at $870 \mathrm{~nm}$ ) on AEA are shown in Figs. 8 and 9 respectively. The regions denoted by " $\mathrm{C}$ " in these figures represent the aerosol conditions in Reno, and likely other cities, in the afternoon when secondary aerosol mass has condensed on soot cores and compacted them by collapse to a more spherical shape. "F" in these figures represents the core sizes and coatings typical of ponderosa pine fire aerosol. "F" and "C" are representative of afternoon aerosol conditions in July (smoky) and August (urban aerosol only), respectively. For an identical core surrounded by a spherical coating with refractive index of $(1.5,0.0 \mathrm{i})$, AEA becomes as large as 1.6, even though the coating is non-absorbing, for example, in the parameter space near point "F" in Fig. 8. It is noteworthy that point " $F$ " in Fig. 8 coincides with typical BC core and coating diameters observed in ponderosa pine smoke (Lewis et al., 2009). To reiterate, the coating need not be absorbing to give an AEA between $405 \mathrm{~nm}$ and

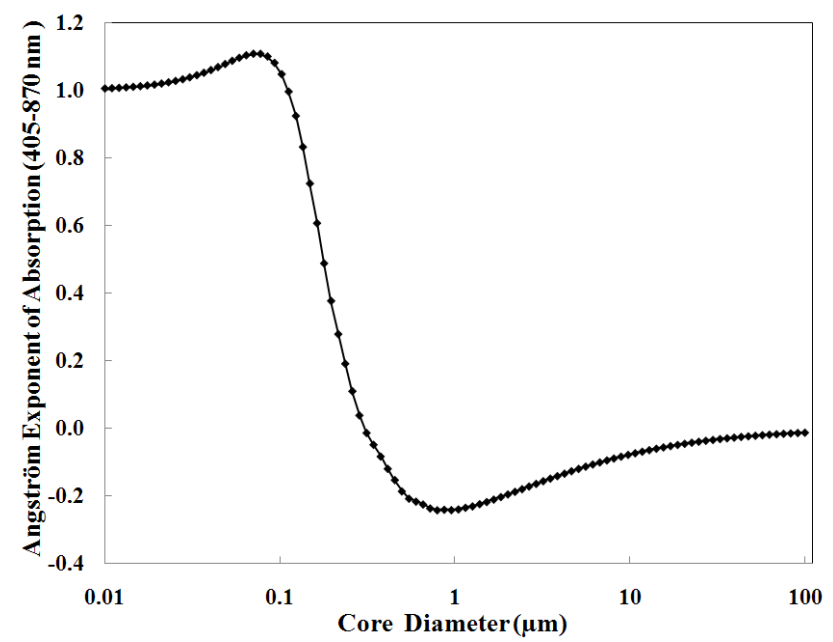

Fig. 7. Ångström exponent of absorption (AEA) as a function of core diameter from Mie theory for the uncoated sphere model for mono-disperse black carbon having a refractive index $(1.55,0.8 \mathrm{i})$.

$870 \mathrm{~nm}$ significantly larger than unity. By contrast, point " $\mathrm{C}$ " in Figs. 8 and 9, representative of the parameter space commonly observed for urban soot when coated and collapsed at mid-day due to secondary aerosol formation on the soot 


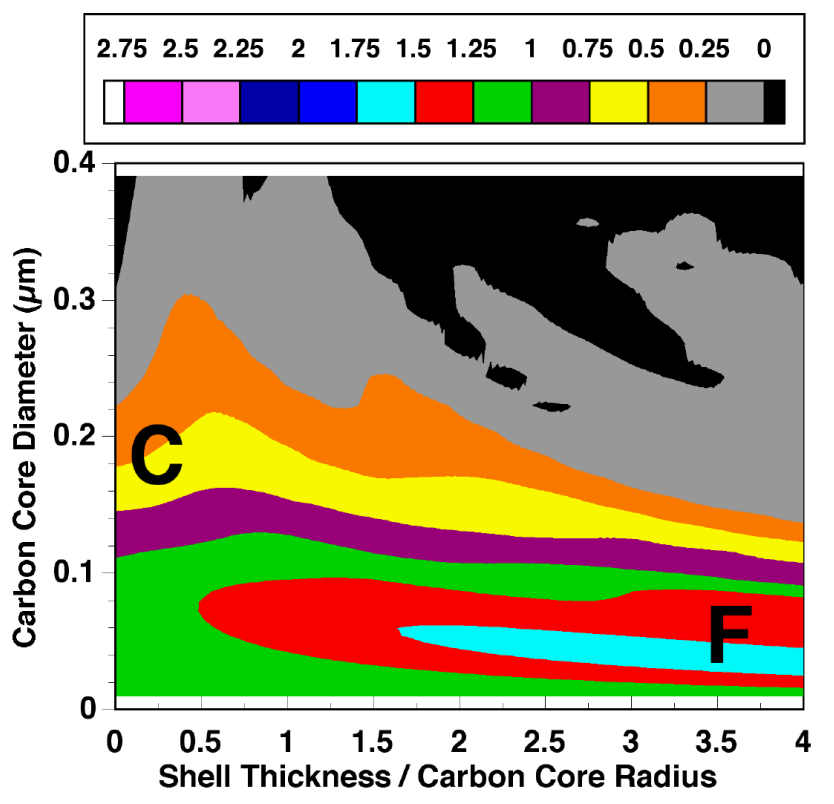

Fig. 8. Simulation of the Ångström exponent of absorption from values at $405 \mathrm{~nm}$ and $870 \mathrm{~nm}$ as a function of coating thickness and core diameter for a core with refractive index $(1.55,0.8 \mathrm{i})$ and a coating with refractive index $(1.5,0.0 \mathrm{i})$. In this case, the coating does not absorb light. The regions denoted by " $\mathrm{C}$ " represent aerosol conditions likely on cities in the afternoon when secondary aerosol has condensed on soot cores and compacted them to a more spherical shape. The regions denoted by "F" represent the core size and coatings typical of ponderosa pine smoke aerosol.

(Schnaiter et al., 2003), corresponds to AEA significantly less than unity for both absorbing and non absorbing coatings. However, freshly emitted soot in the predawn hours before collapse to a more compact shape is likely to have an AEA greater than or equal to unity (Bergstrom et al., 2007) as observed in Fig. 5. These calculations were performed with monodisperse particles. Features, such as the black islands (Fig. 8) and the spiky structures (Fig. 9), are caused by the "Mie wiggles" and will disappear for polydisperse model calculations. The power law enhancement caused by nonabsorbing coatings is also clearly seen with calculations using polydisperse aerosols.

The relative minimum in AEA for typical urban conditions in the afternoon as shown in Fig. 5 is associated with point " $\mathrm{C}$ " in either Figs. 8 or 9. In other words, relatively large carbon cores typical of collapsed primary emissions of soot from motor vehicles in cities when coated with either absorbing or non-absorbing shells have AEA significantly less than unity for wavelengths $405 \mathrm{~nm}$ and $870 \mathrm{~nm}$. By contrast, the smoky month of July, as shown in Fig. 5, has AEA as large as 2, suggesting that the model point "F" in Fig. 9 for the core with an absorbing coating is the correct interpretation for the cause of these observed values of AEA.

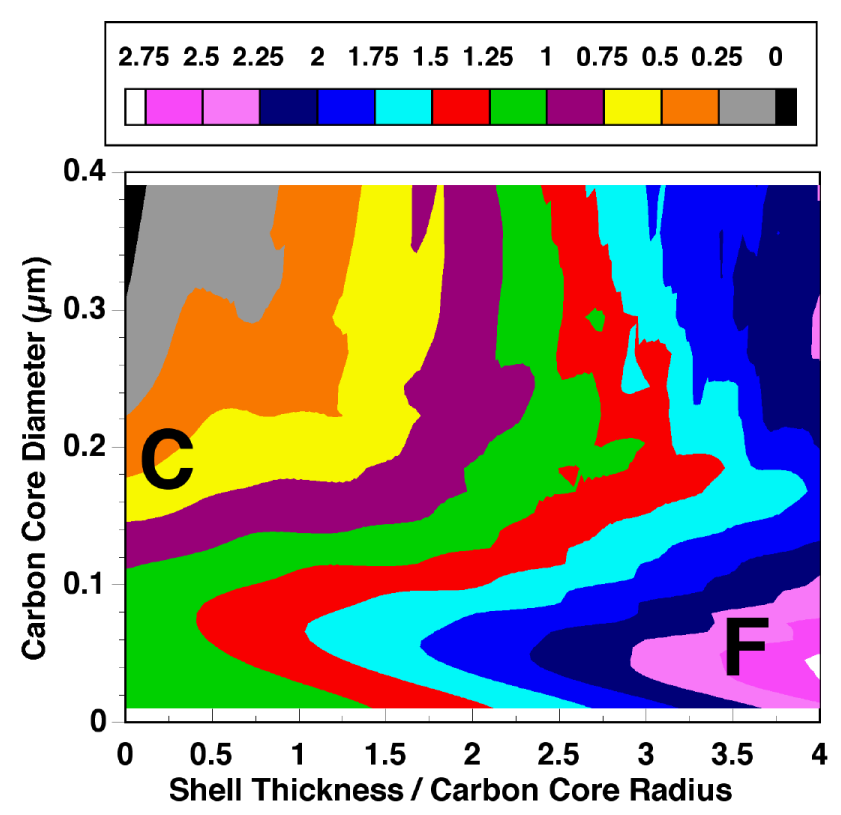

Fig. 9. Same as Fig. 8, though for a core with refractive index (1.55, $0.8 \mathrm{i})$ and a coating with a refractive index of $(1.5,0.012 \mathrm{i})$ at $405 \mathrm{~nm}$ and $(1.5,0.0 \mathrm{i})$ at $870 \mathrm{~nm}$. This coating selectively absorbs light at $405 \mathrm{~nm}$. The regions denoted by " $\mathrm{C}$ " represent aerosol conditions for cities in the afternoon when secondary aerosol has condensed on soot cores and compacted them to a more spherical shape. The regions denoted by "F" represent the core size and coatings typical of ponderosa pine smoke aerosol.

\section{Conclusions}

Our simulations confirm that large AEA values are possible even when coatings do not absorb light, especially when the $\mathrm{BC}$ core is much smaller than the wavelength of the laser used for aerosol optical measurements. The organic coating need not be intrinsically brown to observe effects commonly referred to as those caused by brown carbon light absorption. For relatively small cores, increasing coating thickness increases the AEA while for large cores, AEA does not change dramatically as a function of coating thickness.

On average, during the smoky month of July 2008 aerosol light extinction coefficients observed in Reno, Nevada were about an order of magnitude larger than those observed during the comparably smoke-free month of August 2008. Diurnal variation of aerosol extinction suggests that vertical development of the boundary layer is delayed under smoky conditions, likely due to reduction of the solar forcing at the surface. Comparison with laboratory-generated wood smoke suggests that aerosol optical properties in July are consistent with a predominant fuel source of pine needles and litter.

Measurements in August were typical of urban plumes. Midday values of the AEA were found to be significantly less than unity, as has been noted before. A likely explanation for this effect is that the wavelength range $405 \mathrm{~nm}$ to $870 \mathrm{~nm}$ 
was large, and absorbing particle size is likely larger coincident with low AEA values. Particle absorption could be in the surface area regime at $405 \mathrm{~nm}$, whereas it could be in the volume or resonance regime for $870 \mathrm{~nm}$ for sufficiently large particles. This work illustrates that aerosol optical characteristics can be quite different for vehicular-related and biomass burning aerosol.

Acknowledgements. We acknowledge support by NSF, DOE ASP, JFSP through NPS, and the University of Nevada, Reno. We are grateful to the crew of the FLAME1 experiment in Missoula Montana that resulted in the laboratory data on biomass burning aerosol optics. We acknowledge NASA and Jeffery Reid for providing a satellite image and discussions.

Edited by: E. Weingartner

\section{References}

Abel, S. J., Haywood, J. M., Highwood, E. J., Li, J., and Buseck, P. R.: Evolution of biomass burning aerosol properties from an agricultural fire in southern Africa, Geophys. Res. Lett., 30, 1783, doi:10.1029/2003GL017342, 2003.

Andreae, M. O. and Gelencsér, A.: Black carbon or brown carbon? The nature of light-absorbing carbonaceous aerosols, Atmos. Chem. Phys., 6, 3131-3148, 2006,

http://www.atmos-chem-phys.net/6/3131/2006/.

Arnott, W. P., Moosmüller, H., Rogers, C. F., Jin, T., and Bruch, R.: Photoacoustic spectrometer for measuring light absorption by aerosols: Instrument description, Atmos. Environ., 33, 28452852, 1999.

Arnott, W. P., Moosmüller, H., and Walker, J. W.: Nitrogen dioxide and kerosene-flame soot calibration of photoacoustic instruments for measurement of light absorption by aerosols, Rev. Sci. Instrum., 71, 4545-4552, 2000.

Bergstrom, R. W., Pilewskie, P., Russell, P. B., Redemann, J., Bond, T. C., Quinn, P. K., and Sierau, B.: Spectral absorption properties of atmospheric aerosols, Atmos. Chem. Phys., 7, 5937-5943, 2007 ,

http://www.atmos-chem-phys.net/7/5937/2007/.

Bond, T. C. and Bergstrom, R. W.: Light absorption by carbonaceous particles: An investigative review, Aerosol Sci. Tech., 40, 27-67, 2006.

Bruce, C. W., Stromberg, T. F., Gurton, K. P., and Mozer, J. B.: Trans-spectral absorption and scattering of electromagnetic radiation by diesel soot, Appl. Optics, 30, 1537-1546, 1991.

Chakrabarty, R. K., Moosmüller, H., Arnott, W. P., Garro, M. A., Slowik, J. G., Cross, E. S., Han, J. H., Davidovits, P., Onasch, T. B., and Worsnop, D. R.: Light scattering and absorption by fractal-like carbonaceous chain aggregates: Comparison of theories and experiment, Appl. Optics, 46, 6990-7006, 2007.

Chen, L.-W. A., Moosmüller, H., Arnott, W. P., Chow, J. C., Watson, J. G., Susott, R. A., Babbitt, R. E., Wold, C. E., Lincoln, E. N., and Hao, W. M.: Emissions from laboratory combustion of wildland fuels: Emission factors and source profiles, Environ. Sci. Technol., 41, 4317-4325, 2007.

Chen, L.-W. A., Moosmüller, H., Arnott, W. P., Chow, J. C., Watson, J. G., Susott, R. A., Babbitt, R. E., Wold, C. E., Lincoln, E.
N., and Hao, W. M.: Particle emissions from laboratory combustion of wildland fuels: In situ optical and mass measurements, Geophys. Res. Lett., 33, L04803, doi:10.1029/2005GL024838, 2006.

Clarke, A., McNaughton, C., Kapustin, V., Shinozuka, Y., Howell, S., Dibb, J., Zhou, J., Anderson, B., Brekhovskikh, V., Turner, H., and Pinkerton, M.: Biomass burning and pollution aerosol over North America: Organic components and their influence on spectral optical properties and humidification response, J. Geophys. Res., 112, D12S18, doi:10.1029/2006JD007777, 2007.

Fuller, K. A., Malm, W. C., and Kreidenweis, S. M.: Effects of mixing on extinction by carbonaceous particles, J. Geophys. Res., 104(D13), 15941-15954, 1999.

Hallett, J., Hudson, J. G., and Rogers, C. F.: Characterization of combustion aerosols for haze and cloud formation, Aerosol Sci. Tech., 10, 70-83, 1989.

Hoff, R. M., Palm, S. P., Engel-Cox, J. A., and Spinhirne, J.: GLAS long-range transport observation of the 2003 California forest fire plumes to the northeastern US, Geophys. Res. Lett., 32, L22S08, doi:10.1029/2005GL023723, 2005.

Hudson, P. K., Murphy, D. M., Cziczo, D. J., Thomson, D. S., de Gouw, J. A., Warneke, C., Holloway, J., Jost, H.-J., and Hübler, G.: Biomass-burning particle measurements: Characteristic composition and chemical processing, J. Geophys. Res., 109, D23S27, doi:10.1029/2003JD004398, 2004.

Ito, A. and Penner, J. E.: Global estimates of biomass burning emissions based on satellite imagery for the year 2000, J. Geophys. Res., 109, D14S05, doi:10.1029/2003JD004423, 2004.

Johnson, B. T., Osborne, S. R., Haywood, J. M., and Harrison, M. A. J.: Aircraft measurements of biomass burning aerosol over West Africa during DABEX, J. Geophys. Res., 113, D00C06, doi:10.1029/2007JD009451, 2008.

Kirchstetter, T. W., Novakov, T., and Hobbs, P. V.: Evidence that the spectral dependence of light absorption by aerosols is affected by organic carbon, J. Geophys. Res., 109, D21208, doi:10.1029/2004JD004999, 2004.

Lack, D. A., Cappa, C. D., Covert, D. S., Baynard, T., Massoli, P., Sierau, B., Bates, T. S., Quinn, P. K., Lovejoy, E. R., and Ravishankara, A. R.: Bias in filter-based aerosol light absorption measurements due to organic aerosol loading: Evidence from ambient measurements, Aerosol Sci. Tech., 42, 1033-1041, doi:10.1080/02786820802389277, 2008.

Lewis, K., Arnott, W. P., Moosmüller, H., and Wold, C. E.: Strong spectral variation of biomass smoke light absorption and single scattering albedo observed with a novel dual wavelength photoacoustic instrument, J. Geophys. Res., 113, D16203, doi:10.1029/2007JD009699, 2008.

Lewis, K. A., Arnott, W. P., Moosmüller, H., Chakrabarty, R. K., Carrico, C. M., Kreidenweis, S. M., Day, D. E., Malm, W. C., Laskin, A., Jimenez, J. L., Ulbrich, I. M., Huffman, J. A., Onasch, T. B., Trimborn, A., Liu, L., and Mishchenko, M. I.: Reduction in biomass burning aerosol light absorption upon humidification: roles of inorganically-induced hygroscopicity, particle collapse, and photoacoustic heat and mass transfer, Atmos. Chem. Phys. Discuss., 9, 15247-15294, 2009, http://www.atmos-chem-phys-discuss.net/9/15247/2009/.

Liu, L., Mishchenko, M. I., and Arnott, W. P.: A study of radiative properties of fractal soot aggregates using the superposition T-matrix method, J. Quant. Spectrosc. Ra., 109, 2656-2663, 
doi:10.1016/j.jqsrt.2008.05.001, 2008.

Martins, J. V., Artaxo, P., Liousse, C., Reid, J. S., Hobbs, P. V., and Kaufman, Y. J.: Effects of black carbon content, particle size, and mixing on light absorption by aerosols from biomass burning in Brazil, J. Geophys. Res., 103(D4), 32041-32050, 1998.

Moffet, R. C. and Prather, K. A.: In-situ measurements of the mixing state and optical properties of soot with implications for radiative forcing estimates, PNAS, 106(29), 11872-11877, doi:10.1073/pnas.0900040106, 2009.

Moosmüller, H., Chakrabarty, R. K., and Arnott, W. P.: Aerosol light absorption and its measurement: A review, J. Quant. Spectrosc. Ra., 110, 844-878, doi:10.1016/j.jqsrt.2009.02.035, 2009.

Mulholland, G. W. and Bryner, N. P.: Radiometric model of the transmission cell-reciprocal nephelometer, Atmos. Environ., 28, 873-887, 1994.

Naik, V., Mauzerall, D. L., Horowitz, L. W., Schwarzkopf, M. D., Ramaswamy, V., and Oppenheimer, M.: On the sensitivity of radiative forcing from biomass burning aerosols and ozone to emission location, Geophys. Res. Lett., 34, L03818, doi:10.1029/2006GL028149, 2007.

Oshima, N., Koike, M., Zhang, Y., Kondo, Y., Moteki, N., Takegawa, N., and Miyazaki, Y.: Aging of black carbon in outflow from anthropogenic sources using a mixing state resolved model: Model development and evaluation, J. Geophys. Res., 114, D06210, doi:10.1029/2008JD010680, 2009.

Paredes-Miranda, G., Arnott, W. P., Jimenez, J. L., Aiken, A. C., Gaffney, J. S., and Marley, N. A.: Primary and secondary contributions to aerosol light scattering and absorption in Mexico City during the MILAGRO 2006 campaign, Atmos. Chem. Phys., 9, 3721-3730, 2009,

http://www.atmos-chem-phys.net/9/3721/2009/.

Pfister, G. G., Wiedinmyer, C., and Emmons, L. K.: Impacts of the fall 2007 California wildfires on surface ozone: Integrating local observation with global model simulations, Geophys. Res. Lett., 35, L19814, doi:10.1029/2008GL034747, 2008.

Rahmah, A. A., Arnott, W. P., and Moosmüller, H.: Integrating nephelometer with a low truncation angle and an extended calibration scheme, Meas. Sci. Technol., 17, 1723-1732, 2006.

Redemann, J., Russell, P. B., and Hamill, P.: Dependence of aerosol light absorption and single-scattering albedo on ambient relative humidity for sulfate aerosols with black carbon cores, J. Geophys. Res., 106(D21), 27485-27495, 2001.
Rissler, J., Vestin, A., Swietlicki, E., Fisch, G., Zhou, J., Artaxo, P., and Andreae, M. O.: Size distribution and hygroscopic properties of aerosol particles from dry-season biomass burning in Amazonia, Atmos. Chem. Phys., 6, 471-491, 2006, http://www.atmos-chem-phys.net/6/471/2006/.

Roden, C. A., Bond, T. C., Conway, S., and Pinel, A. B. O.: Emission factors and real-time optical properties of particles from traditional wood burning cookstoves, Environ. Sci. Technol., 40(21), 6750-6757, 2006.

Schnaiter, M., Horvath, H., Möhler, O., Naumann, K. H., Saathoff, H., and Schöck, W.: UV-VIS-NIR spectral optical properties of soot and soot-containing aerosols, J. Aerosol Sci., 34, 14211444, doi:10.1016/S0021-8502(03)00361-6, 2003.

Schnaiter, M., Linke, C., Möhler, O., Naumann, K.-H., Saathoff, H., Wagner, R., and Schurath, U.: Absorption amplification of black carbon internally mixed with secondary organic aerosol, J. Geophys. Res., 110, D19204, doi:10.1029/2005JD006046, 2005.

Schwarz, J. P., Spackman, J. R., Fahey, D. W., Gao, R. S., Lohmann, U., Stier, P., Watts, L. A., Thomson, D. S., Lack, D. A., Pfister, L., Mahoney, M. J., Baumgardner, D., Wilson, J. C., and Reeves, J. M.: Coatings and their enhancement of black carbon light absorption in the tropical atmosphere, J. Geophys. Res., 113, D03203, doi:10.1029/2007JD009042, 2008.

Subramanian, R., Roden, C. A., Boparai, P., and Bond, T. C.: Yellow beads and missing particles: Trouble ahead for filter-based absorption measurements, Aerosol Sci. Technol., 41, 630-637, 2007.

Toon, O. B. and Ackerman, T. P.: Algorithms for the calculation of scattering by stratified spheres, Appl. Optics, 20, 3657-3660, 1981.

Westerling, A. L., Hidalgo, H. G., Cayan, D. R., and Swetnam, T. W.: Warming and Earlier Spring Increase Western US Forest Wildfire Activity, Science, 313, 940-943, 2006.

Yang, M., Howell, S. G., Zhuang, J., and Huebert, B. J.: Attribution of aerosol light absorption to black carbon, brown carbon, and dust in China - interpretations of atmospheric measurements during EAST-AIRE, Atmos. Chem. Phys., 9, 2035-2050, 2009, http://www.atmos-chem-phys.net/9/2035/2009/. 